\title{
An Analysis of Malay-Sino Relations in Malaysia
}

\author{
Aida Idris \\ Faculty of Business and Accountancy, University of Malaya \\ 50603 Kuala Lumpur, Malaysia \\ Tel: 603-7967-3994_E-mail: aida_idris@um.edu.my
}

\begin{abstract}
Having recently celebrated her fiftieth year of independence, Malaysia now needs to take a re-look at some critical issues concerning ethnic relations in the country. With increasing public pressure towards human rights and social equity, certain government initiatives such as the New Economic Policy may warrant a thorough overhaul. Such exercise, however, should only begin based on an improved understanding of the past and present associations among the various ethnic groups. With that in mind the current study sets out to paint a fresh and candid picture of the relationships between the two largest ethnic communities in Malaysia: the Malays and Chinese. This is sought through a review of the literature as well as an analysis of macro-level statistics, in particular the vital statistics, industry figures and mean incomes.
\end{abstract}

Keywords: Malaysia, Ethnic relations, Values, Economic performance

\section{Introduction}

Ethnic relations have always been central to nation-building in a multi-cultural, multi-religious society such as Malaysia. In her fifty years of nationhood friction among particular ethnic groups has surfaced from time to time which affects social and economic developments, and necessitates changes in government policies and programs. Understanding ethnic relations issues in the country is, therefore, critical to its future stability and wellbeing - especially as the population becomes increasingly globalized, more open and more educated. In this paper, focus is given on the two biggest ethnic groups in Malaysia: the Malays and Chinese. The study begins with a historical account of their relationships - from the early days to the present - and proceeds with a comparative analysis of their overall demographics, cultural values, management styles, and economic positions. As the intention is to paint a macro-level picture of the differentials, secondary data are used in the analysis such as vital statistics, industry figures and mean incomes. The findings are expected to provide the basis for further studies in the area, particularly those using primary data from smaller and more specific samples.

\section{The History of Malay-Sino Relations in Malaysia}

The migration of the Malay peoples from Southern China to the Malayan peninsular happened so long ago - estimated at 2,500 to 1,500 B.C. - that they are generally considered as the indigenous, or Bumiputera, population (Hirschman, 1975). Although their origins were rooted in Southern China, these earliest boatmen who came to Malaya through Indochina, Siam and Indonesia, slowly developed their own identity and culture as Malays. Subsequent contact between the Malays and various ethnic groups arose mostly due to religious missionaries and trade relations. Since the coming of the first Indian, Chinese and Arab ships prior to 1,000 A.D. and later the Portuguese envoys in 1511, the Malays have always been exposed to a multitude of external influences in their political, economic and cultural practices. In the present section, the history of Malay and Chinese ethnic relations in Peninsular Malaysia is traced; the findings are organized in three parts, according to chronological order, from pre-independence to post-independence to the future.

\subsection{Pre-Independence (Early History to 1957)}

Malay-Sino relations in the Malayan peninsular began more than a thousand years ago. According to Purcell (1948), the earliest Chinese visits to Malaya in the first millennium were by Buddhist monks and it was not until the $14^{\text {th }}$. Century that trading was mentioned in any Chinese records. The earliest Chinese settlement in Malaya can be traced back to the times of the Malacca Sultanate in the fifteenth century (Yen, 2000). Because of its strategic location, Malacca attracted Chinese traders who remained in the kingdom to conduct their business. To help administer the Chinese community the Sultan appointed a Chinese as one of the four port officials or Shahbandar. Three patterns of Chinese settlement can be observed from the end of the $18^{\text {th }}$. century to the early part of the $20^{\text {th }}$. century (Yen, 2000): The urban port settlement, the mining settlement and the rural agricultural settlement. Out of the three, the urban port community - distributed mainly in the Malaccan Straits trading centres especially Malacca and Penang - was relatively the most open and interacted the most with the Malays. This resulted in a new sub-cultural group called the 
“Cina-Selat”, a Chinese community which until today has observed a great deal of Malay culture, whilst maintaining their ethnic identity. In the other two settlements, Chinese cultures were more closely guarded; secret societies were also common which perpetuated the Chinese' protectiveness over their dialects, kinship and cultural autonomy.

During the British' colonial rule, migration of the Chinese into Malaya flourished as they were encouraged by the British to develop commercial activities especially in tin mining and cash crops such as coffee and sugar cane (Hirschman, 1975). Since these immigrants had little interest in local politics, their relationship with the British administration was considerably better than the Malays'. It is believed (Shaffie and Zainuddin, 2000) that unlike the Malays who viewed the colonials as oppressors who had to be ousted, Chinese immigrants cooperated rather well with the British in their pursuit of economic interests. It was also during this period that the Malays' entrepreneurial class which was largely sponsored by the Malay Sultans - began to dwindle as the loss of sovereignty resulted in trade monopolization by the British and the Malays’ refusal to foster working relationships with the latter (Zamani, 2002).

Political events in China at the turn of the twentieth century affected greatly the overseas Chinese communities. The crushing defeat of China in the first Sino-Japanese War led to the formation of a political group in 1897 in Malacca known as "The Eighteen Saviours" who pledged to overthrow the Manchus in China. Subsequent events such as the "Penang Conference” organized by Sun Yat-Sen in 1910 (Yen, 2000) indicated the strong affinity that the Chinese immigrants had with their homeland, and although internal feuds were rife between the Chinese reformists and revolutionaries in Malaya, overall there was a heightened political awareness among them and gradually a sense of unity emerged. When the Japanese invaded Malaya in 1942, the Chinese community suffered the most (Lee and Heng, 2000). Several thousand Chinese were executed during the "sook-ching" or ethnic cleansing exercise and this prompted some to take up arms against the Japanese Army. One of the more well-known movements was the Malayan People's Anti-Japanese Army (MPAJA), the military wing of the Malayan Communist Party (MCP). Although the British did not support communist ideologies, their more pressing need to regain control over Malaya led them to provide aid to the MPAJA guerillas (Shaffie and Zainuddin, 2000). When the war ended in 1945 - and presumably as a mark of appreciation for the Chinese' resistance against the Japanese - the British announced proposals for the "Malayan Union” which, among other objectives, sought to protect the rights of Chinese immigrants by granting them citizenships equal with the Malays upon independence.

Not surprisingly, the Malayan Union was rejected outright by the Malays. Through dialogues between the British and the Malay elite, the Federation of Malaya was inaugurated in 1948 (Stubbs, 1989) that was more protective of Malay rights and status. However, talks within the All-Malaya Council of Joint Action (AMCJA) between Malay and Chinese representatives failed to reach an agreement on the constitution for an independent Malaya. At around the same time, in response to the British' negative post-war treatment of the communists, the MPAJA guerillas retreated to their jungle bases to wage a rebellion against the British. In the ensuing struggles, many Malays and Chinese found themselves on opposite sides of the conflict - the former as members of the local security forces and the latter as insurgents. Inter-ethnic relations were deeply strained (Stubbs, 1989) and the more moderate wings in both communities realized that this could jeopardise their mutual hope for independence. In the following years the two wings, manifested in the form of political parties - United Malay National Organisation (UMNO) for the Malays and Malayan Chinese Association (MCA) for the Chinese - formed an alliance which agreed to work towards joint success in the 1952 Kuala Lumpur municipal election. Having won that, and together with the Malayan Indian Congress (MIC), they later secured victory in the first national election in 1955 (Lee and Heng, 2000). The alliance then proceeded to negotiate a constitution that was perceived as an acceptable compromise by the British and finally won independence for the country in 1957.

\subsection{Post-Independence (1957 to 2006)}

After independence was proclaimed on 31 August, 1957, the greatest challenge faced by the alliance government was to develop national unity and equity. Considering the huge discrepancies which existed among the three major ethnic groups - especially between the Malays and Chinese - this was no mean feat. More than a century of British colonization had reduced the Malays to the backwater of the nation as small-time farmers and fishermen while the Chinese had prospered as merchants in urban Malaya (Al-Attas, 1991). Therefore, the few years after the initial post-independence euphoria had settled were laced with a strong racial undercurrent. The tension became more pronounced after Singapore was expelled from the federation in 1965 mainly because of irreconcilable differences between Singapore and UMNO regarding Malay-Sino relations (Shaffie and Zainuddin, 2000). The Malays' dissatisfaction with the government's continuing failure to ensure an equitable distribution of wealth finally erupted in the worst racial disturbance ever recorded in the country in what is now known as “Tragedi 13 Mei, 1969".

In an effort to address the social imbalances which led to the bloody incident on May 13, 1969, the government thereafter drafted and implemented the "New Economic Policy" or NEP (Hashim, 2003), an economic plan intended to improve the position of the marginalized - in particular the Malays and Bumiputera - within a period of 20 years (1970 - 1990). At the end of 1990, although the status of the Malays had indeed been elevated, many of the objectives of 
NEP were still unattainable; for instance the targeted 30\% equity ownership by Malay-Bumiputera was still approximately 10\% short (Economic Planning Unit, 1991). When the NEP expired, new drafts called the "National Development Policy (NDP: 1991-2000)" and "National Vision Policy (NVP: 2001-2010)" were adopted by the Mahathir administration as a continuing effort to achieve the original objectives set out in the NEP. During the NEP-NDP period the Malay business class grew substantially - in some sectors such as the wholesale and retail, by as much as 10 times - partly as a result of collaboration with Chinese entrepreneurs (Heng and Sieh, 2000). Ranging from the highly notorious rentier-like “Ali-Baba” relationships to genuine partnerships, many Malay-Sino business ventures prospered by capitalizing on the Malays' political connections and the Chinese' business acumen.

The implementation of government-controlled economic policies such as the NEP-NDP-NVP has inevitably led to a high connection between business and politics in Malaysia (Jomo, 1986). Although UMNO has often used their election victories as evidence of the people's support for these policies, some quarters have been known to perceive them as institutionalised discrimination. Many Chinese politicians and scholars (Siasah, 3-16 Nov. 2006) have questioned the need to provide further support to the Malays when in fact all necessary assistance had already been granted in the first twenty years - with apparently very little result. They also question the validity of official data, suggesting that the Malays have actually secured more than the targeted 30\% equity ownership. Outside the ruling Barisan Nasional, the Malay-based Parti Islam Se-Malaysia (PAS) and the multi-racial Parti Keadilan Rakyat (PKR) have also argued that the above economic policies are discriminatory - and thus immoral - because they favour only selected groups of people who are closely connected to the ruling party (Harakah, 16-30 Nov. 2006). The reformasi movement, mooted in 1998 by the sacked Deputy Prime Minister, Anwar Ibrahim who is now the advisor of PKR, has consistently called for the abolishment of cronyism in public procurement.

In retaliation, conservative Malays have accused dissenting Chinese as communist-sympathisers and traitors who have turned their backs on the "social contract" forged between their forefathers during the pre-independence days (www.malaysia-today.net/Blog-e/2005/08/dont-raise-social-contract-issue-umno.htm). The new generation of Chinese is said to be history-blind; hence the UMNO-led initiative to introduce a new curriculum on inter-ethnic relations in higher learning institutions (The Sun, 20 July 2006) that aim to create awareness among the other ethnic groups of this so-called social contract and perhaps curb their hostile attitude towards the Malays' special privileges.

Malay-Sino relations in post-independence Malaysia have also been inundated with other "sensitive" issues such as educational and cultural freedom. In keeping with the tradition to uphold their ethnic identity, the Chinese in Peninsular Malaysia have always asserted their right for Mandarin-based education and to practise age-old customs such as playing mahjong and worshipping deities. From time to time this has resulted in clashes with some Malay quarters, and been used to the advantage of others, especially politically. For example, the points raised in November 2000 by Suqiu, a Chinese association which champions Chinese education is believed (Lee, 2004) to have caused the Barisan Nasional to lose their Lunas seat to the opposition in a state by-election. Likewise, PAS has often been criticized for demanding a total implementation of an Islamic state which, to the Chinese, will result in the marginalization of the cultural identity (Lee, 2004). With so many issues clouding inter-ethnic unity in Malaysia, the future maintenance of positive Malay-Sino relations remains a challenge. In the next section several perspectives on the subject are presented, particularly with respect to Malaysia's position in a global environment.

\subsection{Now and Beyond}

Having recently celebrated her $50^{\text {th }}$. birthday, Malaysia, as a nation, is still relatively young. Despite her youth, the country boasts of political and economic stability much envied by others far older than she. In the past, however, that stability has been created and maintained through a combination of affirmative action policies such as the NEP, and tough laws such as the infamous Internal Security Act and Official Secrets Act (The Sun, 5 Feb. 2007). As more and more Malaysians start questioning the relevance of such strategies to a society that is becoming increasingly open, educated and modern, the government is now faced with the challenge of maintaining stability through more "democratic" measures. There are calls (Navaratnam, 2007) for the present government to stop focusing on ethnic-based equity ownership and start assessing the effectiveness of past measures in reducing poverty regardless of race and ethnicity. It is argued that the government has deviated from the original objectives of the NEP, which was never really intended to discriminate others in favour of the Malay-Bumiputera group. It is further recommended that Malaysians, of all races, put aside their differences and work together to build the national competitive advantage instead of competing among themselves. This line of thought appears to emphasize the challenges of globalization and liberalization, and expresses concern for the ability of certain ethnic groups to succeed in an open business environment if they are perpetually cloaked in protectionism. In fact such views have gradually gained momentum since the days of the NDP. Ling Liong Sik (1995), the previous president of the MCA, suggests that:

"The main economic goal should be to create a dynamic, resilient and competitive economic structure through policies that are based on the principles of equality of opportunities and merit. In the years beyond 1990, efforts to strengthen 
the economic foundations of our country through policies that reward risk, hard work and enterprise, irrespective of race, must be redoubled." (Ling, 1995, p.22)

Not surprisingly efforts to promote meritocracy and national unity are often met with resistance, especially by Malay and Chinese right-wings. Prior to his resignation in 2003 the then Prime Minister, Dr. Mahathir Mohamad, campaigned for English - due to its international status - to be adopted as the medium in private higher learning institutions; he also introduced the concept of meritocracy in the student intake process in public universities. These moves, although implemented, have been accused (Ali, 2004) of being detrimental to the growth of Malay intellectualism. Likewise, Mahathir's concept of national unity and "Bangsa Malaysia" or the Malaysian Nation has been regarded by some as a threat to the preservation of individual ethnic as well as religious identities (Nawawi, 1989). It appears then that the process of acculturation as described by Western psychologists (Berry and Sam, 1997) is viewed rather negatively by some Malaysians.

There is hope, however, for increased cooperation towards mutual economic benefit - without any community having to sacrifice its ethnic identity. In fact logic dictates that the philosophy of "Unity in Diversity" in multi-ethnic societies is highly relevant to business collaborations because in such organisations, all parties involved share one common goal - the success of the firm - which is attainable through the diverse skills and attributes of its members. In modern management this logic explains the growing tendency, especially among multinational companies, to move away from ethnocentrism towards pluralism (Schermerhorn et al, 1994). From a Muslim's point of view, such a paradigm is reflective of that held by more moderate Muslim scholars including AlQardhawi (1999) and Abdul Rauf (1991) who maintain that cooperation between Muslims and non-Muslims is encouraged, but not to the point of acculturation. Whereas acculturation (Berry and Sam, 1997) describes the transformation of individual ethnic groups into a single nation with common values, the moderate Islamic perspective upholds the need to preserve Islamic identity among Muslims while giving the liberty to non-Muslims to exercise the tenets of their culture and religion, even if they are forbidden in Islam, such as drinking wine and eating pork (Abdul Rauf, 1991).

\section{Analysis of Malay-Sino Differences}

Cross-cultural analysis of the Malay and Chinese communities in Peninsular Malaysia have been a major area of research in various branches of social science including arts, politics, education (Osman, 1988; Kua, 1990) and business (Abdullah, 1996; Lrong, 1998; Sloane, 1999; Fontaine and Richardson, 2003; Omar, 2003). The interest is typically on variances in cultural values, management styles and business performance or economic achievements. Here a review of available literature on these issues is presented; additionally, as background information, differences in some vital statistics such as birth and mortality rates are also provided.

\subsection{Vital Statistics}

Vital statistics refer to population data with respect to its distribution, birth and mortality rates, sex ratio, life expectancy, et cetera (Weeks, 2005) which, in most modern societies, are often used as an indication of the quality and style of life they lead. For instance, a study by Rogers et al (2000) suggests that in the United States higher mortality or death rate among African-Americans compared to whites may be explained by their relatively lower income, higher incidence of infectious diseases such as HIV/AIDS and higher exposure to crimes. These possible causes may, in turn, reflect more underlying cultural values such as their attitude to education and work (Weeks, 2005).

Based on records released by the Malaysian Department of Statistics (2001), the Malay and Chinese ethnic groups in Peninsular Malaysia appear to have vital statistics which are quite distinct from each other. The major differences are compiled in Table 1. The data demonstrates that since the inception of Malaysia the Malays make up the largest ethnic group in Peninsular Malaysia and the Chinese, the second; together the two ethnic groups constitute more than $85 \%$ of the entire population. However, while the Malay population - as a percentage of the whole - shows a generally upward trend, the figure for the Chinese continues to slide downwards. A viable explanation for this may be had by examining the other vital statistics, as follows.

Overall improvements in quality of life are evident in both societies from the trends in death rate and life expectancy and may indicate the success of various social programmes implemented by the government since independence, especially in the areas of health and economy. A snapshot view of the data on life expectancy suggests that the Chinese may have a relatively better health status; for instance in 2000, the life expectancy for the Chinese was 75 years compared to 71 years for the Malays. This may be explained by the former's greater access to more advanced health and medical facilities; it may also reflect their generally healthier attitude towards life. However, if one were to conduct a longitudinal analysis, the improvements are much more noticeable for the Malays who have recorded a higher reduction in death rate and increase in life expectancy. This event is remarkable considering the Malays' more backward status prior to independence; thus Malaysia's social re-engineering seems to have been quite effective in bridging the "quality of life" gap between the two groups. In terms of birth rate, although both groups have recorded a decreasing trend, the Chinese' decline appears to be more drastic. From 1965 to 2000, their rate of birth plummeted by 
17.4\% while the Malays' went down by only 9.9\%. Two possible reasons for this are: One, compared to the Malays, the Chinese may have a more open attitude towards Western medical practices such as contraception and family planning and two, they may have values which emphasise quality over quantity of people.

The above differences in birth and death rates and life expectancy have helped explain why the Malay population has grown at a much higher rate than the Chinese. They also suggest differences in socio-economic status, as well as attitudes and cultural values between the two groups. In the next section, this subject of cultural differences is delved further.

\subsection{Cultural Values}

Studies on ethnic values in Malaysia are mostly conceptual and based on personal experience, rather than strong quantitative analysis. Despite that they are able to provide an initial understanding of the cultural profiles of the individual ethnic groups in the country. The following discussion entails a review of literature on values among the Malay and Chinese societies in Peninsular Malaysia. Although there are similarities in the two cultures, for instance both the Malays and Chinese observe filial piety, courtesy towards others and certain superstitious rituals (Abdullah, 1992), the main objective of the exercise is to emphasise the differences between them.

In “The Malay Ideals”, Zamani (2002) argues that the Malays' cultural identity is inevitably associated with Islam but their interpretations of its teachings are often confused and inaccurate. The Malays are said to be simple-minded, tolerant, loyal, unquestioning and shy, although Islam itself does not advocate unconditional observation of these values. The author cites examples of the Malays' adherence to the notion of sincerety or "ikhlas" and posits that their undue interpretation of the word - i.e. not asking for any form of remuneration - contributes to their simple nature and lack of ambition. Other rigid (mis?)perceptions of certain Islamic concepts such as fate or "takdir", and gratitude or "syukur" are also highlighted to explain the Malays' passive attitude to life. Malay children are said to be discouraged from asking too many questions as it is often interpreted as a sign of impertinence. As a result, they grow up to be obedient and accepting. Some literature on Malay culture (Mohamad, 1981; Karim, 1990) further suggests that the Malays are an emotional race, plagued by outbursts of tantrum or "amuk", and arguably the polar opposite to the Chinese who are often considered practical and pragmatic.

At the same time, the Malays have also been associated with many positive attributes. Idioms such as "Sikit-sikit lama-lama jadi bukit" (Bit by bit, a mountain is built) and "Seperti aur dengan tebing” (Like the river and its bank) respectively describe their patience and cohesiveness. Moreover, the Malays are known for being resourceful as evidenced by the saying "Tiada rotan, akar pun berguna” (When cane is scarce, use roots) while another Malay expression "Biar lambat asalkan selamat" (Slow and steady gets you there safely) indicates their prudence and carefulness. From the Western point of view (Metzger, 1994; Sloane, 1999), the Malays are outstanding for their respect for tradition and "adat” (ancient customs) although there are Muslim scholars (Omar, 2003) who challenge the practise of un-Islamic customs such as "potong jambul" (shaving of the forehead of a newborn) and "bersanding" (bride and groom seated together on a dais in front of the guests), which are believed to have originated from Hinduism. The above views of the Malay ideals, both positive and negative, are ubiquitous in many anthropological studies (Othman, 1993; Wan, 1993) which offer values as the primary explanation for the Malays' social behaviour.

Whereas Malay values accentuate obedience and a strict allegiance to Islam, the Chinese are known more for their openness and free spirit. Purcell (1948) purports that the Chinese have a very liberal attitude towards many aspects of life such as food, clothing and religion. It is said that even though approximately $70 \%$ of Malaysian Chinese are Buddhists (Lee and Heng, 2000), other faiths including Confucianism, Taoism and spiritualism are also embraced simultaneously. In fact many do not identify themselves with any particular religion and merely refer to it as "bai shen” or worshipping deities. The Chinese are also seen to be risk-taking and thrifty (Chee, 1986; Syed et al, 2003), adaptable (Maniam, 1986), as well as ambitious, pragmatic, materialistic and driven by meritocracy (Abdullah, 1992). Some of the above attitudes among Malaysian Chinese appear to be in direct contradiction with the more traditional Confucian values prevalent in Chinese-majority countries such as Mainland China, Taiwan and Hong Kong. According to Ying (2000), the common values in these societies include a strict sense of propriety or morality, veneration for tradition and the elderly, not being guided by profit, and contentment with the present. A study by Pan and Zhang (2003) suggests that the Chinese in the PRC are risk-avoiding. These differences between traditional Confucian values and those observed among Malaysian Chinese - namely propriety versus flexibility, veneration for the elderly versus meritocracy, people-oriented versus profit-oriented, contentment versus ambitiousness and risk-avoiding versus risk-taking - have been attributed by some scholars (Syed et al, 2003; Kuah-Pierce, 2003) to the immigrant history of the Chinese in Southeast Asia; the hardship they experienced as immigrants and minority groups are believed to have reshaped their value orientation towards becoming more venturesome, money-driven and adaptable to their new surroundings.

In terms of Hofstede's cultural dimensions (1980), there have been very few attempts - especially empirical ones - to directly compare the Malay and Chinese societies in Peninsular Malaysia. Nevertheless, there are studies (Mohamad, 
1981; Chee, 1986; Sloane, 1999; Syed et al, 2003) which imply the Malays' association with high collectivism, uncertainty avoidance and power distance, and low masculinity; and the Chinese with high collectivism, power distance and masculinity, and low uncertainty avoidance. However, the above inferences are deduced only through liberal interpretations of other related attitudes and practices because none of the studies specifically employs Hofstede's theoretical framework. For instance from Patricia Sloan's (1999) Islam, Modernity and Entrepreneurship among the Malays, the Malays' collectiveness is concluded based on their spirit of "gotong-royong” rather than a direct reference to collectivism by the author herself. This is perhaps the greatest challenge faced by scholars such as Lrong (1998) who - based on a review of literature - attempts to categorise Malay and Chinese values according to the dimensions of culture proposed by Hofstede (1980). His analysis of extant literature not only helps to sketch an overall picture of the Malays' and Chinese' relationships with the said dimensions, it also contains additional information on the direction and content of the relationships. For instance, he explains:

"In the dimensions of power distance and collectivism, although sharing conceptual similarities, they differ in content. The Malays may be said to be slightly more hierarchical and oriented towards relationship building, and the Malaysian Chinese prefer to incorporate business dealings into the hierarchical relationships as well.” (Lrong, 1998)

Lrong (1998) asserts that since the Malays propagate a hierarchical society, stability, a sense of responsibility to the general public and are relationship-oriented, they may be said to have high power distance and uncertainty avoidance, quite high collectivism and low masculinity. The Chinese, on the other hand, are materialistic, very obedient to the family and loyal to their business clans, and have an open attitude to risks and the unknown; thus they are said to have high masculinity and power distance, quite high collectivism and low uncertainty avoidance. Based on these observations, it is evident that the primary value differences between the Malays and Chinese in Malaysia exist in two dimensions: Masculinity and Uncertainty Avoidance.

\subsection{Management Styles}

Most scholars (Fontaine and Richarson, 2003) agree that Western management theories on national and organizational cultures do to some extent explain Malaysian workplace behaviour; however, they are unable to capture the richness of inter and intra-ethnic relationships which have surfaced following differences in cultural values. Thus it has come as a surprise that there are very few localized cross-cultural studies on Malaysian managers (Fontaine and Richarson, 2003). This section reviews some literature which attempts to explain differences between the Malays' and Chinese' management styles in relation to their cultural values.

Among the more prominent authors on the subject is Abdullah (1992) whose insights have been consulted extensively by multinational corporations operating in the country. In her works she asserts that Malay and Chinese managers, as a result of their culture, have simultaneously similar and contrasting styles of communicating, leading and making decisions. She finds that even though Malaysian managers generally appreciate interpersonal relationships, are religious and put high emphasis on "maruah" (face), some inter-ethnic differences still exist with regards to goal-setting and reward systems. The Malays are said to equate success with good interpersonal relationships and communal wellbeing, and stress these as business goals. The Chinese, on the other hand, place a higher importance on material success; but interestingly, they are more modest in demonstrating their wealth, often describing their business performance as "just enough" or "cukup makan”. According to Syed et al (2003), the Chinese appreciate financial incentives more because they view them as appropriate returns to their hard work and commitment. The Chinese' emphasis on wealth-building should not lead to the conclusion that Chinese managers underestimate the value of interpersonal relationships. On the contrary, studies (Nonini, 1997) show that the concept of "guanxi" or networking is very essential to Chinese organizations. However, while the Malays build relationships to maintain harmony and avoid conflict (Zamani, 2002), the Chinese treat them as opportunities for business growth (Nonini, 1997). They are also more focused on building long-term prosperity for the family; this may explain to some degree their preoccupation with family businesses and succession lines (Liao, 1997; Yu, 2001). Due to the high incidence of family business in the Chinese society, most Chinese managers are paternalistic and controlling (Yeung, 1997). They also look upon business ventures as battles and wars which must be won through the survival of the fittest, a principle in line with Sun Tzu's The Art of War (Syed et al, 2003).

In contrast, Malay managers are widely associated with Islamic management concepts such as "syura” (mediation and consultation), "khalifah” (a wholesome view towards leadership) and “adil” (justice). Muslim managers are not only responsible for the material success of the organization but also for the spiritual well-being of their subordinates (Al-Buraey, 1990). The concepts of "syura" and "khalifah" thus may explain why it is quite common for Malay managers to take interest in employee religiosity, for instance by encouraging their subordinates to pray and fast. The Chinese' style of paternalism cannot be equated with these concepts of "syura" and "khalifah" for the following reason: The former stems from the Chinese' concern for financial success (Yeung, 1997) whereas the latter are aimed at nurturing Muslims' relationship with God. Other Malay management styles which distinguish them from the non-Malays' include conducting business as a "fardhu kifayah" or service to other Muslims - which may explain why 
there is a high incidence of Malay entrepreneurs in the supply of "halal” products such as food and cosmetics. Most Malay managers and entrepreneurs also conscentiously abstain from "haram" or sinful business activities such as gambling, prostitution and selling alcohol as well as participating in "riba” or usury (Ismail, 2001).

\subsection{Economic Structure and Performance}

Much has been said about the differences in work-related values and styles between the Malays and Chinese societies; more importantly they have been attributed as possible reasons for the differences in other aspects of the society particularly its economic structure and performance. The following discussion examines the issue by comparing the industry participation and mean household income for the two ethnic groups. Table 2 shows the industry participation of the Malay and Chinese communities in Malaysia in year 2003 (Department of Statistics, 2004). The last column in the table indicates the percentage difference between the two groups for each industry. It is evident from this column that the largest discrepancies exist in three industries: Wholesale/retail and repair services, public administration/defence and social security, and agriculture/hunting/forestry.

The data suggest an association between the Malay society and public administration as well as agriculture-related industries while the Chinese appear to be associated with trading and more commercial activities. In terms of economic performance, the latter's predominance in trading and commerce appears to be reflected by a distinctly higher household income (Economic Planning Unit, 2000), as shown in Table 3. These findings generally help to strengthen the propositions forwarded by earlier researchers (Lrong, 1998; Omar, 2003) on Malay-Sino differences. In particular the Chinese' connection with enterprise, risk-taking and wealth-building affirms the higher association between the Chinese and masculinity as well as uncertainty avoidance.

\section{Conclusion}

The above study demonstrates the importance of values in social and economic developments. Despite huge government aid to the Malays over the last few decades, they have not been able to achieve the same successes recorded by the Chinese - a situation which suggests problems at a much deeper level than mere infrastructure, training and financial assistance. Future efforts to improve the Malays' economic position should, therefore, concentrate on changing their mindset rather than pumping millions into building more retail spaces and IT supercorridors. In fact questions should be asked as to whether it is the free "handouts" that have nourished the Malays' overdependence on the government, and in turn limited their prospective for growth. At the same time, if greater cooperation is to be fostered between the Malays and Chinese, the latter also needs to go through some value changes. In particular their preoccupation with profit-margins, possibly at the expense of social responsibility, is something that many Malays frown upon and will surely dampen a lot of collaborative potential. The challenge remains for policy-makers and practitioners alike in developing more innovative measures to create a half-way meeting point for these two communities.

\section{References}

Abdul Rauf, M. (1991). Ummah: The Muslim Nation. Kuala Lumpur: Dewan Bahasa dan Pustaka.

Abdullah, A. (Ed.) (1992). Understanding the Malaysian Workforce. Kuala Lumpur: Malaysian Institute of Management.

Al-Attas, S.H. (1991). Mitos Peribumi Malas. Kuala Lumpur: Dewan Bahasa dan Pustaka.

Al-Buraey, M.A. (1990). Management and Administration in Islam. Dhahran: King Fahd University of Petroleum \& Minerals.

Ali, I. (2004). Dilema Neraca Retak. Kuala Lumpur: Sirr Alam.

Al-Qaradhawi, Y. (1999). Fiqh Kenegaraan. Kuala Lumpur: Angkatan Belia Islam Malaysia.

Berry, J.W. and Sam, D.L. (1997). Acculturation and Adaptation. In Berry, J.W., Segall, M.H. and Kagitcibasi, C. (Eds.), Handbook of Cross-cultural Psychology Volume 3 Social Behavior and Applications, 291-326. Needham Heights: Allyn and Bacon.

Chee, P. L. (1986). Small Industry in Malaysia. Kuala Lumpur: Berita Publishing.

Department of Statistics, Malaysia, (2004). Labour Force Survey Report, Malaysia, 2003. Putrajaya.

Department of Statistics, Malaysia (2001). V Vital Statistics Time Series, Malaysia, 1963-1998. Putrajaya.

Economic Planning Unit (2000). Eighth Malaysia Plan. Kuala Lumpur.

Fontaine, R. and Richardson, S. (2003). Cross-cultural Research in Malaysia. Cross-cultural Management, 10(2), 75-89.

Harakah (2006). Umnoputera bolot kekayaan atas nama Bumiputera. 16-30 Nov, 19. Kuala Lumpur. 
Hashim, S. (2003). The NEP and Changes in Poverty and Income Distribution. In Yahaya, J., Teh, N.P. and Yeoh, K.K. (Eds.), Sustaining Growth, Enhancing Distribtuiton: The NEP and NDP Revisited, Kuala Lumpur: CEDER, University of Malaya.

Heng, P.K. and Sieh, L.M.L. (2000). The Chinese Business Community in Peninsular Malaysia, 1957-151999. In Lee. K.H. and Tan C-B. (Eds.), The Chinese in Malaysia, 123-168. Shah Alam: Oxford University Press.

Hirschman, C. (1975). Ethnic and Social Stratification in Peninsular Malaysia, Washington, D.C: American Sociological Association.

Hofstede, G. (1980). Culture's Consequences Second Edition. Thousand Oaks: Sage.

Ismail, M.N. (2001). Paradox of Faith: Is Islam a Hindrance to Business Success. Kuala Lumpur: University Malaya Press.

Jomo, K.S. (1986). A Question of Class: Capital, the State and Uneven Development. Singapore: Oxford University Press.

Karim, W. J. (ed.) (1990). Emotions of Culture: A Malay Perspective. Singapore: Oxford University Press.

Kua, K.S. (1990). Malaysian Cultural Policy and Democracy. Kuala Lumpur: Selangor Chinese Assembly Hall,.

Kuah-Pearce, K.E. (2003). State, Society and Religious Engineering. Singapore: Eastern Universities Press.

Lee, K.H. and Heng, P.K. (2000). The Chinese in the Malaysian Political System. In Lee K.H. and Tan C-B. (Eds.), The Chinese in Malaysia, 194-227. Shah Alam: Oxford University Press.

Lee, K.H. (2004). Differing Perspectives on Integration and Nation Building in Malaysia. In Suryadinata, L. (Ed.), Ethnic Relations and Nation Building in Southeast Asia, 82-108, Singapore: Institute of Southeast Asian Studies.

Liao, S. (1997). Family Business of Ethnic Chinese in Southeast Asia. Chinese Business in Southeast Asia Conference, Kuala Lumpur, 23-25 June.

Ling L. S. (1995). The Malaysian Chinese Towards Vision 2020. Petaling Jaya: Pelanduk Publications.

Lrong, Y. L. (1998). Cultural Attributes of Malays and Malaysian Chinese: Implications for Research and Practice. Malaysian Management Review, 33(2), 81-88.

Maniam, M. (1986). The Influence of Culture in Management in Malaysia. Malaysian Management Review, $21(3)$, 3-7.

Metzger, L. (1994). Kekuatan dan Kelemahan Orang Melayu: Suatu Pandangan Seorang Asing. Jurnal Akademi Pengajian Melayu, 2, 158-175.

Navaratnam, R. (2007). Malaysian Strategic Challenges in 2007 and Beyond: Towards a New National Agenda. Paper presented at the Malaysia Strategic Outlook Conference 2007, 29 Jan, Kuala Lumpur.

Nawawi, M.N. (1989). Dasar Kebudayaan Kebangsaan: Satu Analisis Tentang Pandangan dan Sikap Sarjana-Sarjana Cina. Jurnal Pengajian Melayu 1, 88-97.

Nonini, D.M. (1997). Small-scale Chinese Business in Malaysia in an Era of Flexible Capitalism. Chinese Business in Southeast Asia Conference, Kuala Lumpur, 23-25 June.

Omar, S. (2003). The Malay Lost World with Emphasis on Entrepreneurship. Shah Alam: Anzagain.

Osman, M.T. (1988). Kebudayaan Melayu Dalam Beberapa Persoalan, Kuala Lumpur: Dewan Bahasa dan Pustaka.

Othman, A. H. (1993). Psikologi Melayu. Kuala Lumpur: Dewan Bahasa dan Pustaka.

Pan, F. and Zhang, Z. (2003). Cross-cultural Challenges when Doing Business in China. Singapore Management Review, 26(1), 81-90.

Purcell, V. (1948). The Chinese in Malaysia. London: Oxford University Press.

Rogers, E.M. and Shoemaker, F.F. (1971). Communications of Innovations: A Cross-Cultural Approach. New York: Free Press.

Schermerhorn, J. R., Hunt J. G., and Osborn, R. N. (1994). Managing Organizational Behavior (5 ${ }^{\text {th }}$ ed.). New York: John Wiley.

Shaffie, F. and Zainuddin, R. (2000). Sejarah Malaysia. Shah Alam: Fajar Bakti.

Siasah (2006). Dedah angka sebenar: Kerajaan perlu berani dan bertanggungjawab. 3-16 Nov, 8. Kuala Lumpur.

Sloane, P. (1999). Islam, Modernity and Entrepreneurship among the Malays. London: MacMillan.

Stubbs, R. (1989). Hearts and Minds in Guerilla Warfare: The Malayan Emergency 1948-1960. Singapore: Oxford University Press.

Syed A.W., Saufi, R.A. and Chong K.F. (2003). Family Ties, Hard Work, Politics and Their Relationship with the 
Career Success of Executives in Local Chinese Companies. Malaysian Management Review, 38(1), 1-9.

The Sun (20/7/2006). Dons: We are not involved, 2. Kuala Lumpur.

The Sun (5/2/2007). The "secrets poser", 1. Kuala Lumpur.

Wan A.K. (1993). Beberapa Aspek Masyarakat dan Budaya Melayu, Petaling Jaya: Masfami Enterprise.

Weeks, J.R. (2005). Population: An Introduction to Concepts and Issues. (9 ${ }^{\text {th }}$ ed). Belmont, CA: Wadsworth.

www.malaysia-today.net/Blog-e/2005/08/dont-raise-social-contract-issue-umno.htm

Yen, C-H. (2000). Historical Background. In Lee, K.H. and Tan, C-B. (Eds.), The Chinese in Malaysia, 1-36. Shah Alam: Oxford University Press.

Yeung, H.W. (1997). The Globalisation of Ethnic Chinese Business Firms from Southeast Asia: Strategies, Processes and Competitive Advantage. Chinese Business in Southeast Asia Conference, Kuala Lumpur, 23-25 June.

Ying, F. (2000). A Classification of Chinese Culture. Cross-cultural Management, 7(2), 3-10.

Yu, T.F. (2001). The Chinese family business as a strategic system: an evolutionary perspective. International Journal of Entrepreneurial Behaviour \& Research, 7(1), 22-40.

Zamani, A. (2002). The Malay Ideals. Kuala Lumpur: Golden Books Centre.

Table 1. Vital Statistics of Malay and Chinese Ethnic Groups in Peninsular Malaysia

\begin{tabular}{|c|c|c|c|c|c|c|c|c|}
\hline Vital Event & \multicolumn{2}{|c|}{$\begin{array}{c}\text { Population Distribution } \\
\text { (\%) }\end{array}$} & \multicolumn{2}{c|}{$\begin{array}{c}\text { Birth Rate } \\
\text { (per 1,000) }\end{array}$} & \multicolumn{2}{c|}{$\begin{array}{c}\text { Death Rate } \\
\text { (per 1,000) }\end{array}$} & \multicolumn{2}{c|}{$\begin{array}{c}\text { Life Expectancy* } \\
\text { (yrs) }\end{array}$} \\
\cline { 2 - 9 } Year & Malay & Chinese & Malay & Chinese & Malay & Chinese & Malay & Chinese \\
\hline 1965 & 51.9 & 36.4 & 37.9 & 34.4 & 8.6 & 6.8 & 61.9 & 69.2 \\
1970 & 52.7 & 35.8 & 34.2 & 30.5 & 7.3 & 6.2 & 61.8 & 67.6 \\
1975 & 54.0 & 34.9 & 33.2 & 26.9 & 6.2 & 5.8 & 65.5 & 69.5 \\
1980 & 55.1 & 33.9 & 33.6 & 25.0 & 5.3 & 5.4 & 67.7 & 71.0 \\
1985 & 57.6 & 31.7 & 36.6 & 23.2 & 5.0 & 5.3 & 69.6 & 72.5 \\
1990 & 60.3 & 29.4 & 30.9 & 21.0 & 4.5 & 5.3 & 70.7 & 73.4 \\
1995 & 57.1 & 28.0 & 30.2 & 20.2 & 4.7 & 5.1 & 70.5 & 74.6 \\
2000 & 57.7 & 27.5 & 28.0 & 17.0 & 4.7 & 4.9 & 70.6 & 74.8 \\
\hline
\end{tabular}

* Average between male and female.

Source: Department of Statistics, Malaysia, 2001.

Table 2. Industry participation for the Malay and Chinese Ethnic Groups, 2003

\begin{tabular}{|c|c|c|c|}
\hline Industry & $\begin{array}{c}\text { Malay } \\
(\%)\end{array}$ & $\begin{array}{c}\text { Chinese } \\
(\%)\end{array}$ & $\begin{array}{c}\text { Diff. (M-C) } \\
(\%)\end{array}$ \\
\hline Agriculture, hunting and forestry & 10.5 & 4.9 & 5.6 \\
\hline Fishing & 1.0 & 0.7 & 0.3 \\
\hline Mining and quarrying & 0.3 & 0.2 & 0.1 \\
\hline Manufacturing & 22.8 & 20.2 & 2.6 \\
\hline Electricity, water and gas supply & 0.9 & 0.2 & 0.7 \\
\hline Construction & 7.7 & 12.4 & -4.7 \\
\hline Wholesale and retail; repair services & 12.0 & 30.0 & -18.0 \\
\hline Hotels and restaurants & 7.0 & 7.5 & -0.5 \\
\hline Transport, storage and communication & 5.6 & 4.3 & 1.3 \\
\hline Financial intermediation & 2.4 & 3.3 & -0.9 \\
\hline Real estate, renting and business activities & 3.9 & 5.8 & -1.9 \\
\hline $\begin{array}{l}\text { Public administration and defence; } \\
\text { compulsory social activity }\end{array}$ & 11.1 & 1.1 & 10.0 \\
\hline Education & 8.6 & 4.1 & 4.5 \\
\hline Health and social work & 2.9 & 1.2 & 1.7 \\
\hline Others & 3.1 & 4.0 & -0.9 \\
\hline Total & 100.0 & 100.0 & - \\
\hline
\end{tabular}

Source: Department of Statistics, Malaysia, 2004. 
Table 3. Mean Household Income (RM) for the Malay and Chinese Ethnic Groups, 1990-2000

\begin{tabular}{|c|c|c|}
\hline \multirow{2}{*}{ Year } & \multicolumn{2}{|c|}{ Mean Household Income (RM) } \\
\cline { 2 - 3 } & Malay* & Chinese \\
\hline 1990 & 940 & 1,631 \\
1995 & 1,604 & 2,890 \\
2000 & 1,984 & 3,456 \\
\hline
\end{tabular}

*Data are for the entire Bumiputera community, including the other indigenous groups; however the figures are considered reasonable estimates for the Malays as the other indigenous groups make up only $20 \%$ of the total Bumiputera population.

Source: Economic Planning Unit, Malaysia, 2000. 